\title{
$\mathrm{B}_{4} \mathrm{C}$ と $\mathrm{Ti}$ 粉体間の固相反応による $\mathrm{TiB}_{2}-\mathrm{TiC}$ 複合体の合成
}

\author{
泰松 斉・渥美太郎・岡庭匡史・小玉耕司 \\ 秋田大学工学資源学部材料工学科, 010-8502 秋田市手形学園町 1-1
}

\section{Synthesis of $\mathrm{TiB}_{2}-\mathrm{TiC}$ Composites by the Solid-State Reaction between $\mathrm{B}_{4} \mathrm{C}$ and $\mathrm{Ti}$ Powders}

Hitoshi TAIMATSU, Taroh ATSUMI, Tadashi OKANIWA and Koji KODAMA

Department of Materials Science and Engineering, Faculty of Engineering and Resource Science, Akita University, 1-1, Tegatagakuen-cho, Akita-shi 010-8502

\begin{abstract}
The mechanism of solid-state reaction between $\mathrm{B}_{4} \mathrm{C}$ and $\mathrm{Ti}$ powders has been examined in the temperature range between $1000^{\circ} \mathrm{C}$ and $1300^{\circ} \mathrm{C}$. In the early stage of the reaction, $\mathrm{TiB}$ and nonstoichiometric $\mathrm{TiC}_{0.58}$ in equilibrium with $\mathrm{C}$-saturated $\mathrm{Ti}$ were formed from $\mathrm{B}_{4} \mathrm{C}$ and $\mathrm{Ti}$; then $\mathrm{TiB}_{2}$ and $\mathrm{TiC}_{x}$ containing higher amounts of $\mathrm{C}$ were formed from $\mathrm{TiB}, \mathrm{TiC}_{0.58}$ and remaining $\mathrm{B}_{4} \mathrm{C}$ until the reaction ceased at an $x$-value of 0.69. This reaction path was not changed basically in the temperature range examined although the reaction rate was increased with temperature. Every product grain consisted of a $\mathrm{TiC}_{x}$ core and $\mathbf{a} \mathrm{TiB}_{2}$ layer around the core. This suggests that $B$ hardly migrates in products and the reaction proceeds mainly by inward $C$ diffusion and outward Ti diffusion through the products.
\end{abstract}

[Received January 5, 1999; Accepted August 23, 1999]

Key-words : Solid-state reaction, Titanium boride, Titanium carbide, Boron carbide, Titanium, Displacement reaction

\section{1. 緒 言}

チタンの炭化物, ホウ化物, 窒化物は, 高硬度で, 化学的安 定性に優れるため, 耐摩耗性が要求される部材にサーメットと して用いられている．これら化合物自体はいずれも難焼結性で あるため, サーメット以外には広く利用されるまでに至ってい ない。しかし, 比較的軽量であり, また, 導電性のため放電加 工ができるという特長を持ち合わせているので, 種々の部材へ の応用の可能性がある.このため, ホットプレスや HIP など の加圧焼結によるち密化の研究が盛んである. 近年, このよう な単純な加圧焼結だけでなく，焼結中に反応を生じさせながら ち密化させる，反応性加圧焼結が試みられている．これらは 種々の加圧焼結法と燃焼合成反応1) 3) や固相置換反応 ${ }^{4) ~ 6) ~}$ 組み合わせて化合物の合成とち密化を同時に行うものである. 固相置換反応法は，燃焼合成法に比べると反応熱を利用するこ とはできないが，反応がより遅いので，反応過程を制御するこ とが可能である.このため, 反応中の物質移動に伴う原子の再 配列による微細組織の制御が期待できる点で興味ある方法であ る.この方法によってセラミックスを合成，ち密化するために は，反応過程に関する詳しい情報が不可欠である，そこで本研 究では, $\mathrm{TiB}_{2}-\mathrm{TiC}$ 複合セラミックスの固相置換反応法による 合成, ち密化を目的として, $\mathrm{B}_{4} \mathrm{C}$ と $\mathrm{Ti}$ 間の固相反応過程を詳 しく調べ, 反応機構を検討した.

\section{2. 実 験}

$\mathrm{Ti}$ 粒子の周囲をより細かい $\mathrm{B}_{4} \mathrm{C}$ 粒子が取り巻く反応系にな るように, 固相反応の試料として微細な $\mathrm{B}_{4} \mathrm{C}$ 粉末（レアメタ リック製, 純度 $99 \%$ ） と比較的粗い Ti 粉末（レアメタリック 製, 純度 $99.5 \%$ ）を用いた。レーザー散乱法粒度分布測定装置 （島津製作所製，SALD-1100）によって測定した粒度分布を 図 1 に示す. $\mathrm{Ti}$ 粉末は平均粒径 $24.5 \mu \mathrm{m}$ で, $\mathrm{B}_{4} \mathrm{C}$ 粉末は 0.2 $\mu \mathrm{m}$ 付近と $5 \mu \mathrm{m}$ 付近の 2 か所にピークがあり, 平均粒径は $1.5 \mu \mathrm{m}$ であった. これらの粉末を, 定比の反応

$$
\mathrm{B}_{4} \mathrm{C}+3 \mathrm{Ti} \longrightarrow 2 \mathrm{TiB}_{2}+\mathrm{TiC}
$$

を想定したモル比 $\mathrm{Ti} / \mathrm{B}_{4} \mathrm{C}=3$ ， あるいはモル比を変えて秤量 し, 混合した。これらの混合粉末を $200 \mathrm{MPa}$ の圧力で円柱状 に成形して反応試料とした． Ti の関与する反応は酸素の影響 を激しく受けるので, Ar 中, あるいは石英管中に真空封入し て反応させた。真空封入での反応の場合は，試料を $120^{\circ} \mathrm{C} て ゙$ $24 \mathrm{~h}$ 乾燥させた黒鉛シート (東洋炭素製, 不純物 : $\mathrm{Li} 0.9, \mathrm{Mg}$ 57, Al 130, Si 1100, K 1, V 0.5, Fe 150 wt ppm) でくるみ， ス ポンシ Ti とともに透明石英管中に真空封入後, $1100^{\circ} \mathrm{C}$ に保持 した炉内に投入し, 所定時間反応させた. Ar 中での反応の場 合は, 黒鉛の容器に入れ, $\mathrm{Ar}$ 雲囲気下で $1000 \sim 1300^{\circ} \mathrm{C}$ 温度 で反応させた．この際，できるだけ昇温中の反応を防ぐため， $800^{\circ} \mathrm{C}$ な゙は $250^{\circ} \mathrm{C} \cdot \mathrm{h}^{-1}$ で, それ以上では $600^{\circ} \mathrm{C} \cdot \mathrm{h}^{-1}$ で昇温し た. 反応させた後の試料は, 粉末 $\mathrm{X}$ 線回折装置（日本電子製, JDX-3530）で生成物の分析を行うとともに，EPMA（日本電 子製，JXA-733）を用いて生成物組織と元素分布を調べた.

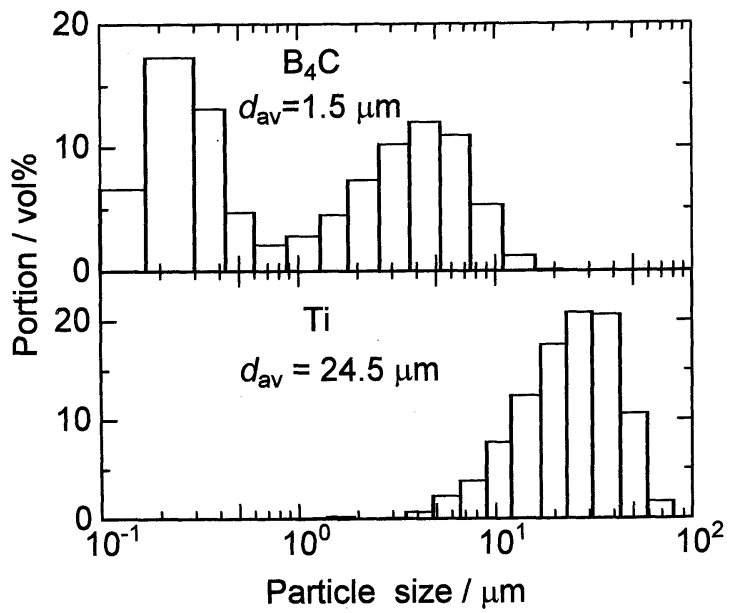

Fig. 1. Distribution of the particle sizes of $\mathrm{B}_{4} \mathrm{C}$ and Ti powders. 


\section{1 反応生成物}

\section{3. 結果及び考察}

混合時のモル比 $\mathrm{Ti} / \mathrm{B}_{4} \mathrm{C}=3$ のときに完全に反応すると，そ の反応は (1) 式になる。しかし， $\mathrm{TiC}$ は広い範囲の不定比性を 有することが知られており7),8), 定比の反応は生じにくいと考 えられる. 本研究では，まず(1)式の反応が生じるかどうかに ついて調べた.

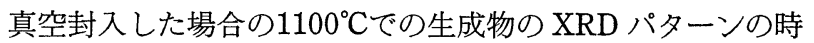
間変化を図 2 に示す. 反応初期では $\mathrm{TiB}$ と $\mathrm{TiC}$ が生成し, 時 間の経過とともに TiB がなくなり, 最終的に $\mathrm{TiB}_{2}$ と $\mathrm{TiC}$ が 生成した. 生成物の種類と時間変化の詳細については後で述べ る. $\mathrm{TiC}$ を除く生成物の XRD ピークの $2 \theta$ 位置は反応時間に よって変化しなかったが, $\mathrm{TiC}$ のピークは, 図 3 に示すよう に時間とともに変化した． TiC は幅広い不定比性を有するの で，このピーク位置の移動は，不定比性の変化による格子定数 の変化に対応していると考えられる.

生成した $\mathrm{TiC}$ の格子定数の反応時間による変化を図 4 に示 す. 格子定数の変化は, $\mathrm{Ar}$ 中の場合と真空封入の場合では異 なった．反応初期には格子定数は時間とともにほぼ同じように 増加するが, $16 \mathrm{~h}$ を経過すると Ar中では逆に減少した。

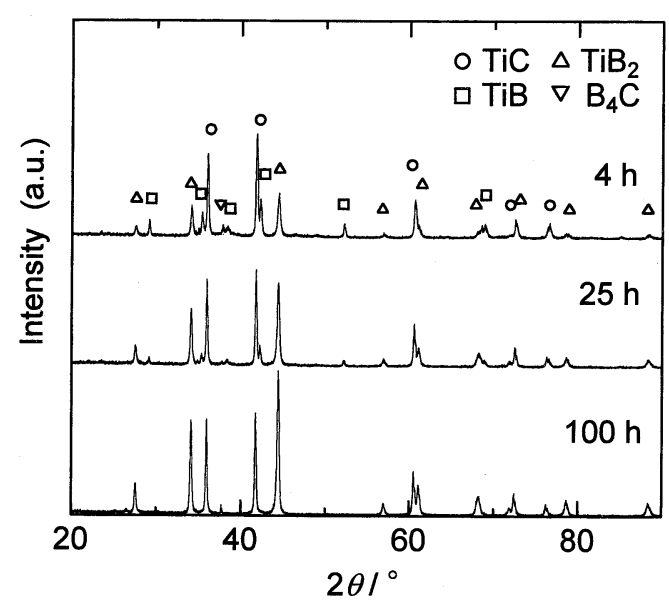

Fig. 2. X-ray diffraction patterns of products formed in vacuum at $1100^{\circ} \mathrm{C}$ ( $\mathrm{Cu} \mathrm{K} \alpha$ radiation).

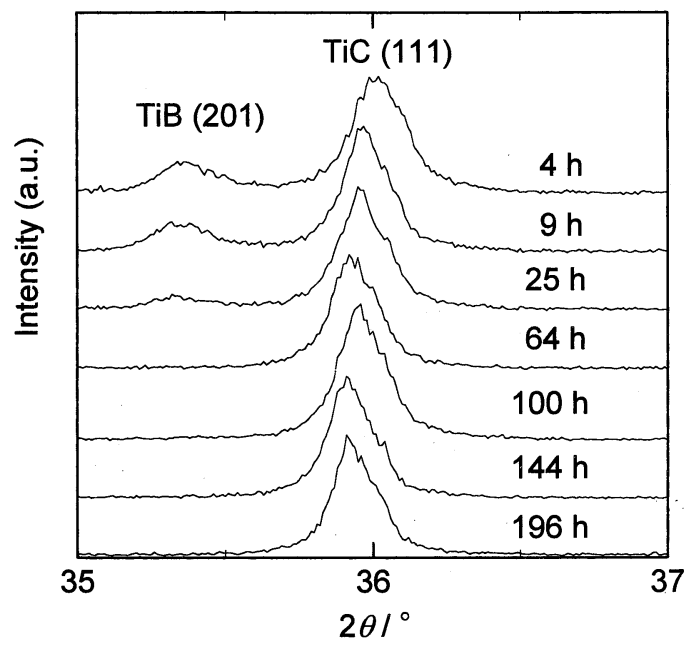

Fig. 3. X-ray diffraction peaks of the (111) plane of $\mathrm{TiC}$ in products formed in vacuum at $1100^{\circ} \mathrm{C}(\mathrm{Cu} \mathrm{K} \alpha$ radiation).
Storms $^{7)}$ は, 報告されていた種々の $\mathrm{C} / \mathrm{Ti}$ 比の $\mathrm{TiC}$ の格子定数 を検討し，格子定数と不定比性の関係を求めた。この関係は Miracle と Lipsitt9)によってその後確認されているように，そ の信頼性は高い. Stormsの求めた関係によると, $\mathrm{TiC}_{x}$ と表し たとき, 格子定数は, $x=0.5$ のときの $0.4299 \mathrm{~nm}$ から $x$ の増加 に従って増加し， $x=0.84$ で最大値 $0.4331 \mathrm{~nm}$ になり，それ以 上では逆に減少し， $x=1.0$ のとき $0.4327 \mathrm{~nm}$ である.また，格 子定数は固溶した酸素の影響を受け, 酸素量が増えると減少す る. $\mathrm{Ar}$ 中での実験は真空封入に比べてガ入中の微量の酸素や 水分による酸素の供給が大きいので, 反応の初期では影響が少 ないが，時間が経過すると固溶酸素量の増加によって格子定数 が低下したと考えられる. 真空封入の場合には格子定数は $0.4325 \mathrm{~nm}$ で一定となったが，これは $x=0.69$ に対応する.し たがって, TiCは，反応の進行に伴って，Cを固溶した金属

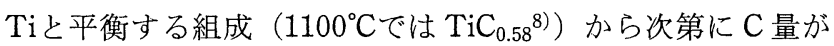
増加し, $64 \mathrm{~h}$ 経過後, $\mathrm{TiC}_{0.69}$ で反応が終了したと考えられ, それ以上は $\mathrm{C}$ 量が増加しない。

真空封入した場合と $\mathrm{Ar}$ 中の場合の生成割合の時間変化を 図 5 に示す。ここでは，生成割合の尺度として各生成物に関す る XRD の最強ピークのピーク相対強度比 $I_{\mathrm{X}} / \Sigma I_{\mathrm{X}}$ を用いた。

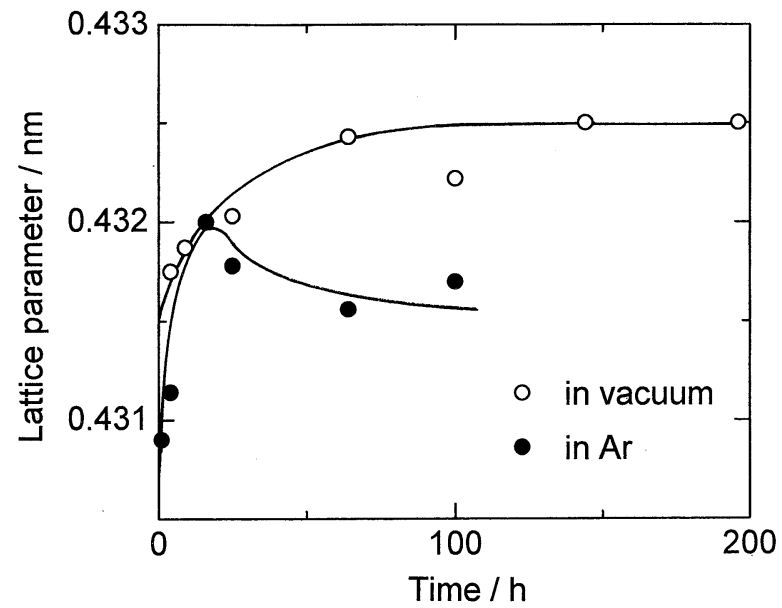

Fig. 4. Change in the lattice parameter of $\mathrm{TiC}$ in products formed in vacuum and Ar with time.

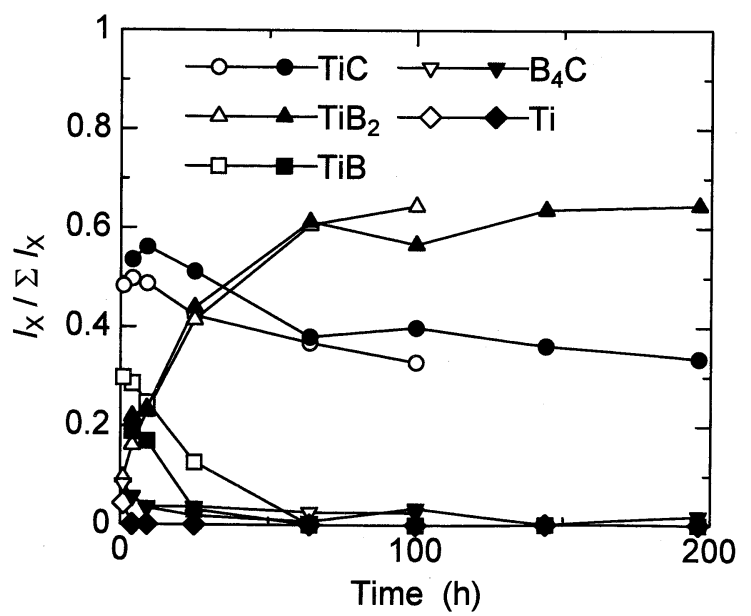

Fig. 5. Change in relative intensity ratio, $I_{\mathrm{X}} / \Sigma I_{\mathrm{X}}$, with time for products formed at $1100^{\circ} \mathrm{C}$. Closed symbols: in vacuum, open symbols: in Ar. 
試料温度が $1100^{\circ} \mathrm{C}$ 到達した時点ですでに $\mathrm{TiC}, \mathrm{TiB}$ と若干の $\mathrm{TiB}_{2}$ が生成していた. 反応時間が経過するに従って, $\mathrm{TiB} か ゙$ 減少し, それとともに $\mathrm{TiB}_{2}$ が増加した. $64 \mathrm{~h}$ 以上経過すると 反応は終了していたと考えられるが， $\mathrm{B}_{4} \mathrm{C}$ は少し残留してい た. $\mathrm{TiC}_{0.69}$ で反応が終了するとして, 生成物に残留する $\mathrm{B}_{4} \mathrm{C}$ のモル分率を計算すると，0.042になる。

図 5 から明らかなように, 生成物の種類及び生成割合の時 間変化については $\mathrm{Ar}$ 中の場合と真空封入の場合で差は認めら れなかったので, $1100^{\circ} \mathrm{C}$ 以外の温度での反応の進行について

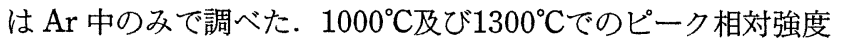
の反応に伴う時間変化を図 6 と図 7 に示す. $1000^{\circ} \mathrm{C}$ でも反応 温度に到達した時点ですでに TiB と TiCは生成しており， $\mathrm{TiB}$ の減少とともに $\mathrm{TiB}_{2}$ が増加した. $1300^{\circ} \mathrm{C}$ 場合は, 温度 が高いため, $24 \mathrm{~h}$ 後には反応が終了していたが, 他の温度の 場合と同様, 反応後も少量の $\mathrm{B}_{4} \mathrm{C}$ が残留していた.

混合時のモル比 $\mathrm{Ti} / \mathrm{B}_{4} \mathrm{C}$ を変えて, $\mathrm{Ar}$ 中で $1200^{\circ} \mathrm{C}, 64 \mathrm{~h}$ 反 応させたときの生成物のピーク相対強度とモル比の関係を図 8 に示す。 モル比 $\mathrm{Ti} / \mathrm{B}_{4} \mathrm{C}$ が 3 から 3.36 までは反応後に $\mathrm{B}_{4} \mathrm{C}$ が 残留していたが，3.43以上では XRDで認められなくなった. $1200^{\circ} \mathrm{C} に お い て も \mathrm{TiC}_{0.69}$ で反応が完了するとして，そのとき の混合のモル比を計算すると $\mathrm{Ti} / \mathrm{B}_{4} \mathrm{C}=3.45$ になり，この比は

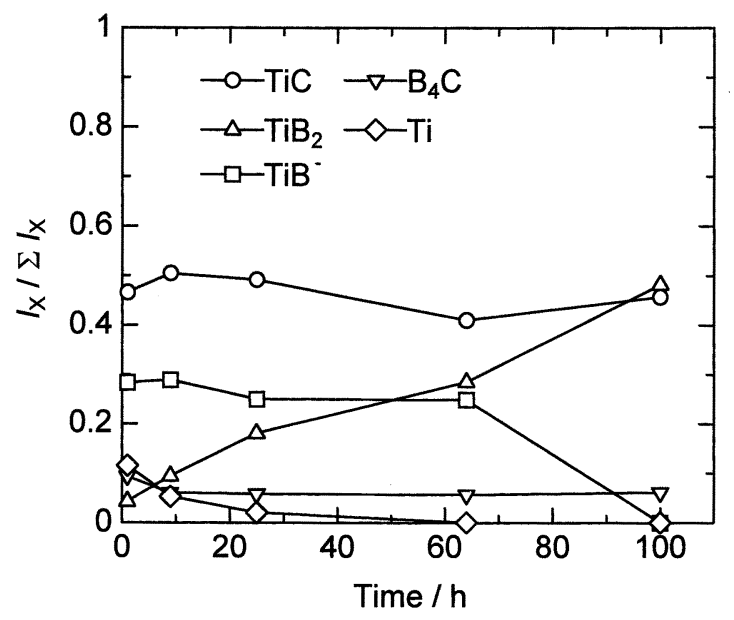

Fig. 6. Change in relative intensity ratio, $I_{\mathrm{X}} / \Sigma I_{\mathrm{X}}$, with time for products formed in $\mathrm{Ar}$ at $1000^{\circ} \mathrm{C}$.

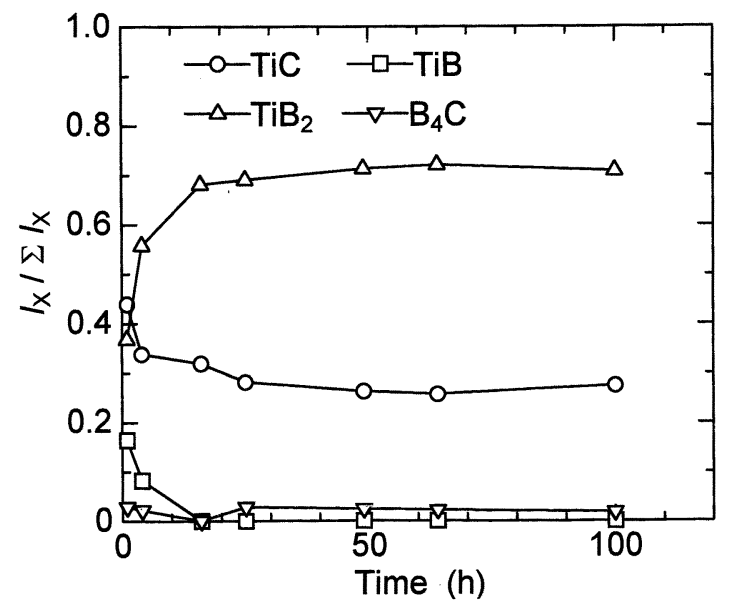

Fig. 7. Change in relative intensity ratio, $I_{\mathrm{X}} / \Sigma I_{\mathrm{X}}$, with time for products formed in $\mathrm{Ar}$ at $1300^{\circ} \mathrm{C}$.

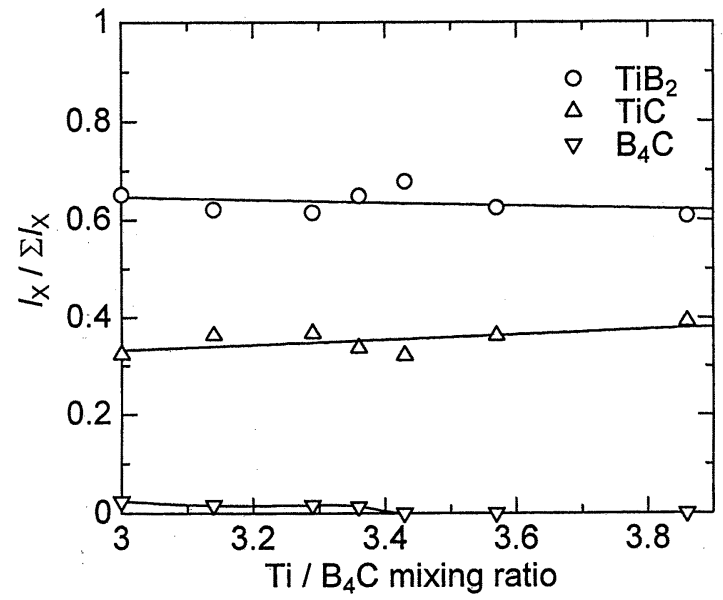

Fig. 8. Relation between relative intensity ratio, $I_{\mathrm{X}} / \Sigma I_{\mathrm{X}}$, for products formed at $1200^{\circ} \mathrm{C}$ and $\mathrm{Ti} / \mathrm{B}_{4} \mathrm{C}$ mixing ratio for starting powders.

\section{実験結果とよく合う.}

本研究では, $\mathrm{Ti}-\mathrm{B}$ 系化合物として $\mathrm{TiB}$ と $\mathrm{TiB}_{2}$ の生成が確 認できた. しかし, $\mathrm{Ti}$ と $\mathrm{TiB}_{2}$ の間の平衡相としては, $\mathrm{TiB}$ 以 外に $\mathrm{Ti}_{3} \mathrm{~B}_{4}{ }^{10), 11)}$ の存在が知られており, 状態図中10)では $\mathrm{Ti}_{3} \mathrm{~B}_{4}$ は低温まで安定である。これまで研究された $\mathrm{TiB}_{2}$ 生成の燃焼 合成及び固相反応合成では, $\mathrm{TiB}_{2}$ 以外に $\mathrm{TiB}$ と $\mathrm{Ti}_{3} \mathrm{~B}_{4}$ が生成 している場合5),6),12),13) と TiB しか生成していない場合4)があ る，これらの合成条件を詳しく検討すると， $\mathrm{Ti}_{3} \mathrm{~B}_{4}$ が生成して いる場合に共通するのはいずれも $1600^{\circ} \mathrm{C}$ 以上の高温で合成が 行われていることで, 生成していないのは本研究と同様の $1500^{\circ} \mathrm{C}$ 以下のときである. $\mathrm{Ti}_{3} \mathrm{~B}_{4}$ が生成しない場合がある理由 をこれらの結果からのみで推定することは無理であるが, 一つ の可能性として, $\mathrm{Ti}_{3} \mathrm{~B}_{4}$ が熱力学的に安定に存在できる温度範 囲が限られており，1500 $1600^{\circ} \mathrm{C}$ 付近以下になると TiB と $\mathrm{TiB}_{2}$ に分解するのかもしれない.

\section{2 生成物の微細組織}

$1300^{\circ} \mathrm{C}, 49 \mathrm{~h}$ 反応後の生成物の微細組織を図 9 に示す. 生成 物のち密化はあまり進行しておらず，反応前の Ti 粒の形状が そのまま残っていた．図 9(b)に示すように個々の大きな粒の 内部は微細な結晶粒からできている. B は粒の外周に沿う部分 に多く，中心部に少し分布している．それに対して，Cは粒の 内部に多く分布している. Ti は粒内に均一に分布して抢り, $\mathrm{XRD}$ の結果とあわせて考えると, $\mathrm{B}$ の多い部分は $\mathrm{TiB}_{2}$ 相, $\mathrm{C}$ の多い部分は $\mathrm{TiC}$ 相に対応する. 図 9 に示した組織は, 本 実験よりずっと高い $1800^{\circ} \mathrm{C}$ (実際の試料温度は約 $1990^{\circ} \mathrm{C}$ ) で $\mathrm{B}_{4} \mathrm{C}$ と Ti の固相反応を起こさせながら通電加圧焼結して得た 緻密な $\mathrm{TiB}_{2}-\mathrm{TiC}$ 複合体の組織6) と基本的に同じである.この ことは, $1300^{\circ} \mathrm{C}$ 上でも反応機構が変化しないことを示して いる

\section{3 反応機構}

得られた結果を総合すると, $1000 \sim 1300^{\circ} \mathrm{C}$ の間では, 高温 になるほど反応速度は増加するが, 反応の進行過程は変化せ ず，次の 2 段階で反応すると考えられる，すなわち，反応の 初期段階では,

$$
0.175 \mathrm{~B}_{4} \mathrm{C}+\mathrm{Ti} \longrightarrow 0.699 \mathrm{TiB}+0.301 \mathrm{TiC}_{0.58}
$$

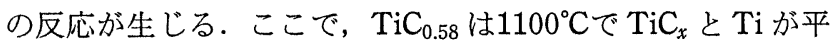
衡する組成 ${ }^{8}$ に相当する. その後,

$0.115 \mathrm{~B}_{4} \mathrm{C}+0.699 \mathrm{TiB}+0.301 \mathrm{TiC}_{0.58}$

$\longrightarrow 0.580 \mathrm{TiB}_{2}+0.420 \mathrm{TiC}_{0.69}$ 

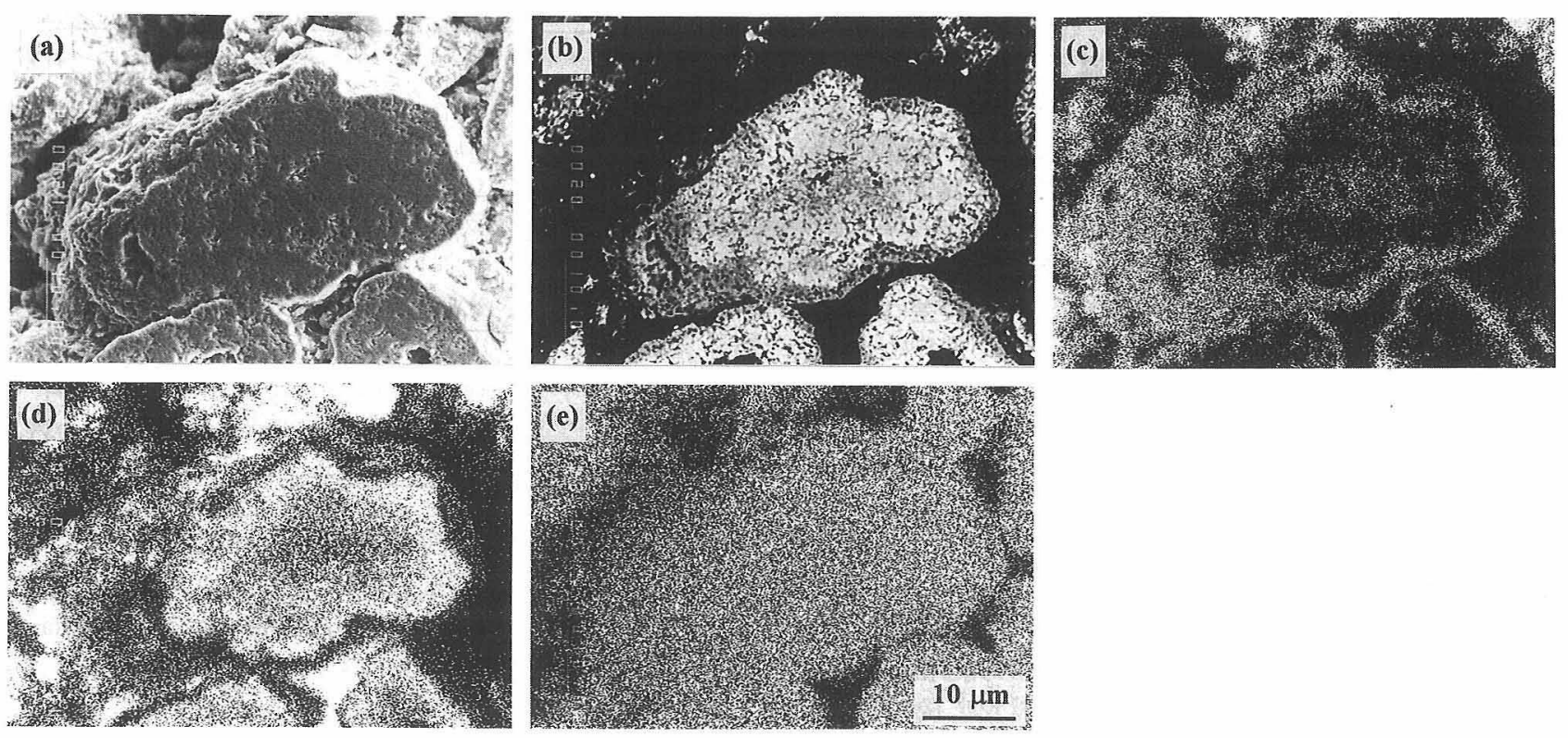

Fig. 9. Microstructure of products after reaction at $1300^{\circ} \mathrm{C}$ for $49 \mathrm{~h}$ : (a) secondary electron image, (b) back-scattered electron image and (c), (d) and (e) distribution images of $\mathrm{B}, \mathrm{C}$ and $\mathrm{Ti}$, respectively.

の $\mathrm{TiB}_{2}$ 生成反応がより遅い速度で進行し, $\mathrm{TiC}_{x}$ の $\mathrm{C}$ 量が増 加する. 総括反応は,

$$
0.290 \mathrm{~B}_{4} \mathrm{C}+\mathrm{Ti} \longrightarrow 0.580 \mathrm{TiB}_{2}+0.420 \mathrm{TiC}_{0.69}
$$

で表される．この反応過程を模式的に示すと図10のようにな る. 生成物の外部が $\mathrm{TiB}_{2}$ 相, 内部が $\mathrm{TiC}_{x}$ 相の 2 層構造であ るということは, 本来外部にあったBはあまり移動せず, 主 に生成物中の Ti の外方への拡散と C の内方への拡散によって 反応が進行したことを示唆している.このように反応が進行す る原因は, 結局, 不定比 $\mathrm{TiC}_{x}$ の高い格子欠陉濃度のために $\mathrm{TiC}_{x}$ 相中の物質移動が速いことによる. 不定比 $\mathrm{TiC}_{x}$ の速い物 質移動は, Ti と C を原料とする TiCの加圧自己燃烧焼結にお いて不定比性が増すほどち密化する傾向がめる2),3)ことからも うかがえる。

本研究で調べた反応々類似の固相反応である $\mathrm{Ti}+\mathrm{C} \rightarrow \mathrm{TiC}$ 及 び $\mathrm{T} i+2 \mathrm{~B} \rightarrow \mathrm{TiB}_{2}$ は非常に大きな発熱を伴い，このため $\mathrm{TiC}$ と $\mathrm{TiB}_{2}$ は燃焼合成することができる1) 3),14)，燃焼合成できる かどうかについての一つの尺度は反応の断熱温度 $T_{\mathrm{ad}}^{14) \sim 16) て ゙ ~}$ ある. $\mathrm{T} \mathrm{i}+\mathrm{C}=\mathrm{TiC}$ の反応では，

$$
\begin{aligned}
& \Delta H_{298}^{\circ}(\mathrm{TiC})+\int_{298}^{T_{\mathrm{mp}}} C_{p}(\mathrm{TiC}, \mathrm{s}) \mathrm{d} T+\Delta H_{\mathrm{f}}(\mathrm{TiC}) \\
& +\int_{T_{\mathrm{mp}}}^{T_{\mathrm{mal}}} C_{p}(\mathrm{TiC}, 1) \mathrm{d} T=0
\end{aligned}
$$

を満足する $T_{\mathrm{ad}}$ を求めればよい。ここで， $\Delta H_{298}^{\circ}$ は $\mathrm{TiC}$ の標 準生成熱, $C_{p}(\mathrm{TiC}, \mathrm{s})$ と $C_{p}(\mathrm{TiC}, \mathrm{l})$ は固体と液体の $\mathrm{TiC}$ の熱

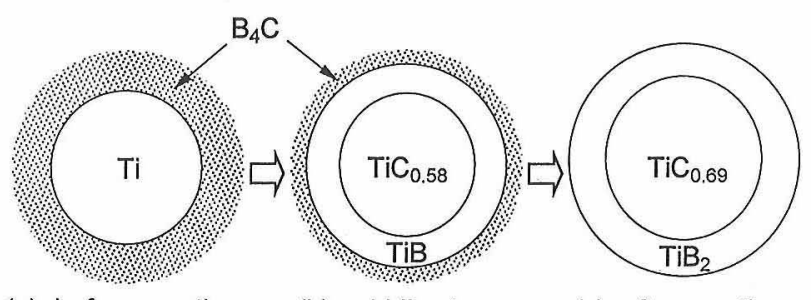

(a) before reaction

(b) middle stage

(c) after reaction

Fig. 10. Schematic drawing of the solid-state reaction between $\mathrm{B}_{4} \mathrm{C}$ and $\mathrm{Ti}$.
容量, $T_{\mathrm{mp}}$ は $\mathrm{TiC}$ の融点, $\Delta H_{\mathrm{f}}(\mathrm{TiC})$ は $\mathrm{TiC} の$ 融解熱である. $\mathrm{Ti}+2 \mathrm{~B}=\mathrm{TiB}_{2}$ の反応の場合は，(5)式に対応する $\mathrm{TiB}_{2}$ の熱力 学諸量を代入すればよい. 熱力学データ17) $\left(\mathrm{TiB}_{2}\right.$ の融解熱に ついては文献18)）を用いて計算すると, $\mathrm{TiC}$ では $3225^{\circ} \mathrm{C}$ ( $\mathrm{TiC}$ の融点), $\mathrm{TiB}_{2}$ では $3067^{\circ} \mathrm{C}\left(\mathrm{TiB}_{2}\right.$ の融点）に達する. $\mathrm{B}_{4} \mathrm{C}$ と $\mathrm{Ti}$ の反応が(1)式であるとすると, この反応の発熱量 も非常に大きく,

$$
\begin{aligned}
& 2 \Delta H_{298}^{\circ}\left(\mathrm{TiB}_{2}\right)+\Delta H_{298}^{\circ}(\mathrm{TiC}) \\
& \quad+\int_{298}^{T_{\text {mp }}}\left\{2 C_{\mathrm{p}}\left(\mathrm{TiB}_{2}, \mathrm{~s}\right)+C_{p}(\mathrm{TiC}, \mathrm{s})\right\} \mathrm{d} T \\
& +\Delta H_{\mathrm{f}}\left(\mathrm{TiB}_{2}\right)+\int_{T_{\mathrm{mp}}}^{T_{\mathrm{xd}}}\left\{2 C_{p}\left(\mathrm{TiB}_{2}, 1\right)+C_{p}(\mathrm{TiC}, \mathrm{s})\right\} \\
& \quad \times \mathrm{d} T=0
\end{aligned}
$$

より，断熱温度は $3067^{\circ} \mathrm{C}\left(\mathrm{TiB}_{2}\right.$ の融点）になり, $\mathrm{TiB}_{2}$ の断熱 温度と同じである.しかし， $\mathrm{B}_{4} \mathrm{C}$ と $\mathrm{Ti}$ の反応は本研究で示し たように然焼合成のような激しい反応ではない， $\mathrm{B}_{4} \mathrm{C}$ と Tiの 反応に関するこれまでの研究では, 然焼が生じている場合13) と燃焼が生じていない場合5,6)がある。燃焼が生じている昜合 は成形体に直接着火している.しかし, この場合でも, TiC や $\mathrm{TiB}_{2}$ の燃焼反応より 1 けた以上燃焼速度が遅いと報告され ている13). 燃焼が生じていない場合は本実験のように $\mathrm{B}_{4} \mathrm{C}$ と Ti の成形体を電気师中で加熱めるいは通電加熱によって昇温 している. 昇温速度が遅い場合，低温時に徐々に反応して，生 成した生成物が拡散の障壁になり，反応速度を低下させるの で，直接着火よりは然焼しにくいと思われる．これらのことか ら考えると， $\mathrm{B}_{4} \mathrm{C}$ と $\mathrm{T}$ 䛀応は，高い発熱量にもかかわら ず，燃焼するかどうかの境界に位置するいえる.

混合比 $\mathrm{Ti} / \mathrm{B}_{4} \mathrm{C}=3$ の試料で $\mathrm{TiB}$ が生成する初期反応(2) 式 が生じると,

$$
\mathrm{B}_{4} \mathrm{C}+3 \mathrm{Ti} \longrightarrow 0.476 \mathrm{~B}_{4} \mathrm{C}+2.096 \mathrm{TiB}+0.904 \mathrm{TiC}_{0.58}
$$

の反応でおよそ半分の $\mathrm{B}_{4} \mathrm{C}$ が反応に関与せず残留し，これが 希釈剂として作用寸る. この反応の $T_{\mathrm{ad}}$ を求めるには $\mathrm{TiC}_{0.58}$ の熱力学的性質が必要である. $\mathrm{TiC}_{0.58}$ の生成熱は組成の関数 として求められており, $\Delta H_{298}^{\circ}=-118 \cdot \mathrm{kJ} \cdot \mathrm{mol}^{-1}$ であるが19), 
熱容量の測定はない。そこで, 熱容量に関してNeumannKopp の法則を適用して, $C_{p}\left(\mathrm{TiC}_{0.58}\right)=C_{p}(\mathrm{TiC})-0.42 \times C_{p}(\mathrm{C})$ として,

$$
\begin{aligned}
& 2.096 \Delta H_{298}^{\circ}(\mathrm{TiB})+0.904 \Delta H_{298}^{\circ}\left(\mathrm{TiC}_{0.58}\right) \\
& \quad-0.524 \Delta H_{298}^{\circ}\left(\mathrm{B}_{4} \mathrm{C}\right)+\int_{298}^{T_{\mathrm{xd}}}\left\{2.096 C_{p}(\mathrm{TiB}, \mathrm{s})\right. \\
& \left.+0.904 C_{p}\left(\mathrm{TiC}_{0.58}\right)-0.476 C_{p}\left(\mathrm{~B}_{4} \mathrm{C}\right)\right\} \mathrm{d} T=0
\end{aligned}
$$

より断熱温度を求めると $1945^{\circ} \mathrm{C}$ (熱力学的性質が $\mathrm{TiC}$ と同じ であると仮定すると $2148^{\circ} \mathrm{C}$ ） となる．この断熱温度は $\mathrm{TiC} や$ $\mathrm{TiB}_{2}$ の断熱温度よりもずっと低く, 燃焼しにくいことを示し ている.

後期の反応 (3) 式の速度は, 反応の Gibbs 自由エネルギー変 化が(2)式よりも小さいこと, 及び, 図10に示したように, 反 応の進行のためにはすでに生成した TiB の層を通って Ti と Cが移動しなければならないことにより, 初期反応(2)式より も更に低い. 以上のことから， $\mathrm{B}_{4} \mathrm{C}$ と $\mathrm{Ti}$ の反応では断熱温度 が高いにもかかわらず然焼が生じなかった理由は, 電気炬内で 昇温していること，1段目の反応の発熱量が小さいこと， 2 段 目の反応が緩慢であることであると考えられる.

\section{4. 結 論}

$\mathrm{TiB}_{2}-\mathrm{TiC}$ 複合セラミックスの合成を目的として, 1000 $1400^{\circ} \mathrm{C}$ の温度範囲で $\mathrm{B}_{4} \mathrm{C}$ と $\mathrm{Ti}$ 粉末間の固相反応過程を調べ た. 温度が高くなるにつれて反応速度は高くなるが, 反応機構 は基本的には変化しなかった。 反応の初期段階では, $\mathrm{B}_{4} \mathrm{C}$ と $\mathrm{Ti}$ の固相反応で $\mathrm{TiB}$ と不定比の $\mathrm{TiC}_{0.58}$ が生成し, その後, 残留している $\mathrm{B}_{4} \mathrm{C}$ と中間生成物の $\mathrm{TiB}$ と $\mathrm{TiC}_{0.58}$ の 3 相の反 応で $\mathrm{TiC}_{x}$ 中の $\mathrm{C}$ 量を増加させながら $\mathrm{TiB}_{2}$ と $\mathrm{TiC}_{0.69}$ が生成し た。得られた反応生成物は粒状をしており, 粒の外周部は $\mathrm{TiB}_{2}$ 相, 内部は主に $\mathrm{TiC}$ 相からできていた．このことは， $\mathrm{Ti}$ の周囲にあった B はあまり移動せず, 主として生成物中の $\mathrm{Ti}$ の外方への拡散と C の内方への拡散によって反応が進行した ことを示唆している. このような反応の進行は, 不定比 $\mathrm{TiC}_{x}$ 相中での速い物質移動に起因すると考えられる.
謝 辞 本研究は文部省科学研究費補助金基盤研究 (C) (2) (課 題番号09650727）によって行われたことを記し，感謝の意を表し ます。

\section{文 献}

1) Y. Miyamoto, M. Koizumi and O. Yamada, J. Am. Ceram. Soc., 67, C224-25 (1984).

2) O. Yamada, Y. Miyamoto and M. Koizumi, J. Am. Ceram. Soc., 70, C206-08 (1987).

3) L. J. Kecskes, T. Kottke and A. Niiler, J. Am. Ceram. Soc., 73, 1274-82 (1990).

4) F. Olevsky, P. Mogilevsky, E. Y. Gutmanas and I. Gotman, Met. Mater. Trans. A, 27A, 2071-79 (1996).

5) M. W. Barsoum and B. Houng, J. Am. Ceram. Soc., 76, 144551 (1993).

6) S. Sugiyama, M. Kimura, K. Asari, T. Yoshida and H. Taimatsu, J. Jpn. Soc. Powder Powder Metall., 45, 1065-70 (1998) [in Japanese].

7) E. K. Storms, "The Refractory Carbides," Academic Press, New York (1967) pp. 1-17.

8) T. B. Massalsky, "Binary Alloy Phase Diagrams, Vol. 1, 2nd. ed.," The Materials Information Soc., Materials Park (1990) p. 114.

9) D. B. Miracle and H. A. Lipsitt, J. Am. Ceram. Soc., 66, 59297 (1983).

10) K. E. Spear, P. McDowell and F. McMahon, J. Am. Ceram. Soc., 69, C4-5 (1986).

11) R. G. Fenish, Trans. Metall. Soc. AIME, 236, 804 (1966).

12) V. A. Neronov, M. A. Korchagin, V. V. Aleksandrov and S. N. Gusenko, J. Less-Common Metals, 82, 125-29 (1981).

13) J. W. McCauley, N. D. Corbin, T. Restar and P. Wong, Ceram. Eng. Proc., 3, 538-54 (1982).

14) J. B. Holt and Z. A. Munir, J. Mater. Sci., 21, 251-59 (1986).

15) Z. A. Munir, Am. Ceram. Soc. Bull., 67, 342-49 (1988).

16) H. C. Yi and J. J. More, J. Mater. Sci., 25, 1159-68 (1990).

17) O. Kubaschewski, C. B. Alcock and P. J. Spencer, "Materials Thermochemistry, 6th ed.," Pergamon, Oxford (1993) pp. 257-323.

18) O. Knacke, O. Kubaschewski and K. Hesselmann, "Thermodynamical Properties of Inorganic Substances, 2nd ed.," Springer Verlag, Berlin (1991) p. 2109.

19) V. M. Maslov, A. S. Neganov, I. P. Borovinskaya and A. G. Merzhanov, Fiz. Goreniya. Vzryva, 14, 73-82 (1978). 